\section{Training Alabama Garden Center Employees}

\author{
Mary B. Musgrove', \\ J. David Williams ${ }^{2}$, \\ Bridget K. Behe ${ }^{3}$, and \\ Kenneth M. Tilt ${ }^{4}$
}

Additional index words. survey

Summary. Before analyzing the responses of Alabama garden center employees about the training they had received, we determined how satisfied 100 Alabama Master Gardeners were with the employee-s who helped them in the store from which they most often purchased plants for their homes, landscapes, or gardens. We mailed the primary survey to $\mathbf{4 7 2}$ employees of 130 retail garden center businesses in Alabama to determine the percentage of employees who received job training and the amount, frequency, and methods of training they received while working for their current employers (37\% responded). Employees were categorized as managers $(28 \%)$ or subordinate employees $(\mathbf{7 2 \%})$ and fulltime $(\mathbf{7 2 \%})$ or part-time $(28 \%)$. Fortyfour percent of the employees had received some training at the time they were hired. Training continued for $68 \%$ of the respondents. Only $39 \%$ of the employees had a written description of their job responsibilities discussed with them. Most $(85 \%)$ believed the training they received had prepared them to do their jobs well, but $82 \%$ said more training would increase their confidence in their work performance. Most employees were trained by one-on-one instruction $(60 \%)$ and small-group sessions (5 or fewer persons) $(65 \%)$. Few employees received training from videotapes $(5 \%)$ or educational seminars $(26 \%)$, and most that did were managers and full-time employees.

Extension associate.

${ }^{2}$ Assistant professor.

${ }^{3}$ Associate professor.

${ }^{4}$ Associate professor.

Auburn University Department of Horticulture. Alabama Agricultural Experiment Station journal no. 11955044. batch project no. 851. The cost of publishing this paper was defrayed in part by the payment of page charges. Under postal regulations, this paper therefore must be hereby marked advertisement solely to indicate this fact.
A s the lawn and garden retailing industry becomes more competitive, it is important to the horticulture industry that garden centers survive and provide the products and services that consumers expect. Unless consumers are educated about the products and services garden centers offer, they may purchase lawn and garden goods from other retailers. Johnson (1989) identified a lack of skilled employees as the most significant problem in garden center operation at retail garden centers in Alabama.

Retail garden centers are important to the horticulture industry because of their role in linking the nursery producer to consumers. In general, garden centers display an image of high product quality, knowledgeable employees, availability of a wide product selection, and excellent service (Barton, 1988). In a survey of garden centers, Powell (1991) reported that price was one of the least important factors that influenced a customer's choice of a garden center. The three most influential factors in customer choice of a garden center were selection $(21 \%)$, quality (16\%), and service $(13 \%)$.

Niemiera et al. (1993) cited a study performed by the Horticultural Research Institute reporting that garden center consumer education is the most essential element in achieving sales. In their Phoenix, Ariz., study of garden-center customers, Niemiera et al. (1993) found that only $17 \%$ of respondents had a specific idea of which plants they wanted to purchase at the garden center before arrival, indicating the need for information presentation and customer assistance.

An organized and systematic training program should accompany the hiring of all new employees. Ford and Heaton (1980) maintained that, because a business continually changes and employees will always have a need for satisfaction with their work, ongoing employee development should be part of the operating plan of any business. One nursery owner reported a fear, common throughout the garden-center industry, that training is a waste of time and effort. The benefits gained, however, far exceed the initial investment made (Higginbotham, 1992).

The purpose of this study was to provide information, by surveying gar- 
den-center employees and knowledgeable consumers of gardening products, to owners and managers of retail garden centers to aid their management and operation. We asked a segment of gardening consumers, in a telephone survey, what characteristics were important to them in choosing retail stores in Alabama that sell ornamental plants. We then determined the level of job training provided to employees of garden centers in Alabama using employee responses from a mail survey.

\section{Materials and methods}

Master Gardener survey. The Master Gardener program is a 10week course of study in horticulture and allied subject matter areas primarily designed for the homeowner or nonprofessional horticulturist. People with diverse interests and backgrounds participate in this program. Master Gardeners comprise an important segment of gardeners.

One hundred certified Master Gardeners were randomly selected from a list of 850 to respond to a pretested, seven-item telephone survey. We obtained telephone numbers from County Extension offices, current Master Gardener mailing lists, and telephone directories and conducted telephone interviews between the hours of 5 and 7 PM on weekday evenings in October and November 1992.

Employee-training survey. A 59item questionnaire was developed with questions in closed- and open-ended question formats to collect information about employee training. We then selected a sample of 130 retail garden centers from the Alabama Nursery men's Association membership directory and telephone directories. All retail nursery and garden-center businesses listed in city and county metropolitan areas in Alabama with popula- tions greater than or equal to 15,000 were included in the sample. This list encompassed the 38 highest populated metropolitan areas in Alabama.

We mailed a letter to each of 130 garden-center owners on 29 May 1992, explaining the nature and purpose of the garden-center employee-training study and asking that the owner distribute the questionnaires that would be sent within a few days to each of their employees, allowing time for completion. We mailed questionnaire packages on 1 June 1992. Each package contained a cover letter; ten postage-paid, business-reply envelopes; a letter of instruction; and a questionnaire to be given to each employee. The package also contained a sample questionnaire and business-reply postcard for owners to list the number of employees participating and the number of additional questionnaires needed, if any.

We made follow-up telephone calls to all garden centers three weeks after the initial mailing to confirm the number of employees and verify whether the business was, in fact, a retail garden center. Sixteen businesses were eliminated from the sample for two reasons: 1) the business was not a retail garden center, or 2) the business had no employees other than the owner and family members. We sent two follow-up mailings to owners, the first on 26 June 26 and the second on 7 Aug. 1992.

The employee-training questionnaire included four categories of questions: 1) employee job-description characteristics, 2) employee beliefs about training, 3) the amount, methods, and frequency of training employees received from their current employers, and 4) employee demographic characteristics.

Raw data were collected and analyzed using the Statistical Analysis System (SAS) to provide frequencies, per- centages, means, and nonparametric statistical testing, using the chi-square and Wilcoxon Rank Sum tests to show differences between managerial and subordinate-level employees and between full-time and part-time employees.

\section{Results and discussion}

Master Gardener survey. The largest group of respondents $(65 \%)$ said they purchased most of the plants for their homes, landscapes, or gardens from retail garden-center stores. Nineteen percent of the Master Gardeners said they purchased most of their plants at mass-merchandise stores, and $16 \%$ said they bought plants mostly from feed and seed/coop stores. Quality was the most important factor for $51 \%$, followed by selection (22\%) and convenience $(12 \%)$.

No demographic information was collected in this survey, other than gender. The sample of respondents surveyed included $62 \%$ females and $38 \%$ males. Data analysis with the Statistical Analysis System (SAS) was used to compare two large, mutually exclusive groups, the Master Gardeners who purchased most of their plants from mass-merchandise store and Master Gardeners who purchased most of their plants from garden centers to determine differences on three variables: 1) the importance of plant quality, price, and selection in making their store choices, 2) their perceptions of the availability of store employees to help them, and 3) their levels of confidence in employees' knowledge of plants and abilities to answer questions.

Nearly twice as many garden center Master Gardeners as mass-merchandise Master Gardeners said quality was the most important factor in their choosing where to buy their plants. The mass-merchandise group was more than twice as likely to select stores based on price, suggesting a

Table 1. Comparison of manager and subordinate employee positions group means on four variables.

\begin{tabular}{|c|c|c|c|}
\hline Variable & Manager & Subordinate & $P$ \\
\hline $\begin{array}{l}\text { No. months employed by current employer } \\
\text { (during 6/91-6/92) }\end{array}$ & $10.7(n=48)$ & $8.0(n=118)$ & $0.0001^{\star}$ \\
\hline $\begin{array}{l}\text { Average no. hours worked per week } \\
\text { (during April 1992) }\end{array}$ & $51.0(\mathrm{n}=48)$ & $37.9(n=116)$ & $0.0001^{*}$ \\
\hline No. years worked for current employer & $5.2(\mathrm{n}=46)$ & $2.1(\mathrm{n}=115)$ & $0.0001^{*}$ \\
\hline
\end{tabular}

"Significant at $\mathrm{P} \leq 0.10$. 
Table 2, Comparison of garden-center employees by position on six variables regarding sources of their formal horticulture education.

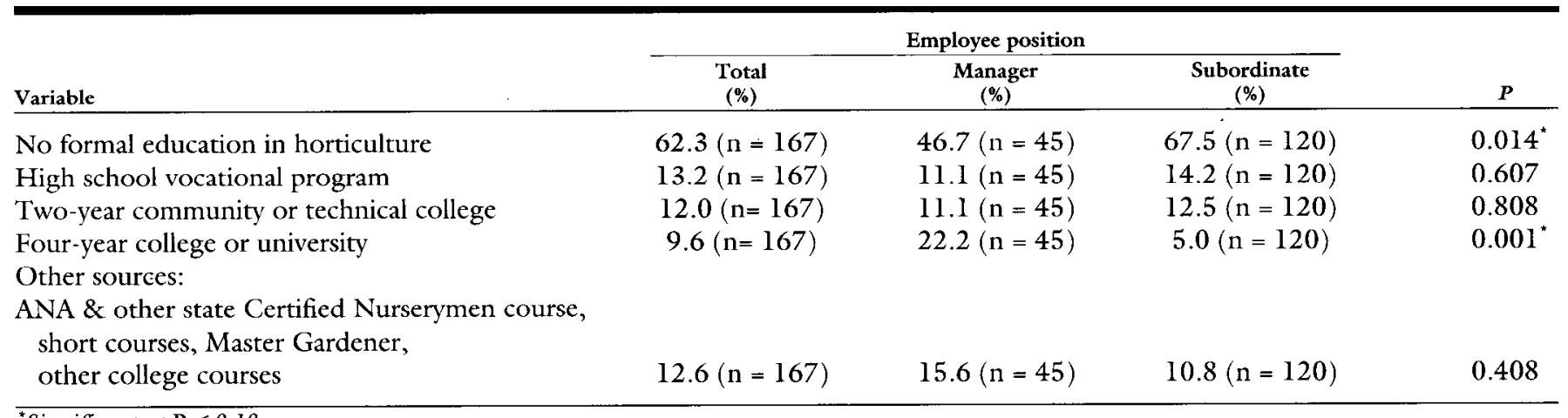

"Significant at $\mathrm{P} \leq 0.10$

different type of customer who probably would not be loyal to one store type in shopping for plants.

Another difference between these two groups was their perceived availability of employees. More than four times as many garden center Master Gardeners as mass-merchandise Master Gardeners said store employees were frequently available to help customers. This perception of available employees may reflect on the customer's perceptions of level of service available from that retailer.

Notably more garden center Master Gardeners had a high level of con- fidence in the employees at the stores where they purchased plants, demonstrated by the group mean of 3.7 (rated on a scale of 1 to 5 , where $1=$ least and $5=$ most). Since Master Gardeners have at least some horticultural education and much interest and experience in plants, their expectations are possibly higher than those of most gardeners. However, neither the mass-merchandise Master Gardener group mean (2.1) nor the garden center Master Gardener group mean was close to the highest possible rating, indicating that most Master Gardeners believed that those employees' knowledge about plants could improve.

Employee-training survey. Onehundred seventy six employees from 56 garden centers in Alabama returned questionnaires for a $37 \%$ response rate. There was about a three to one ratio of subordinate employees ( $72 \%$ ) to managers (28\%) among the respondents. Mean hours respondents worked per week during April 1992 was $41.7 \mathrm{~h}$. Managers worked significantly more hours per week (51 h/week) than subordinate employees ( $38 \mathrm{~h} /$ week). Because only $28 \%$ of employees were categorized as pm-time employees and April is one of the busiest months

Table 3. Comparison of manager and subordinate employee positions on 16 job training variables.

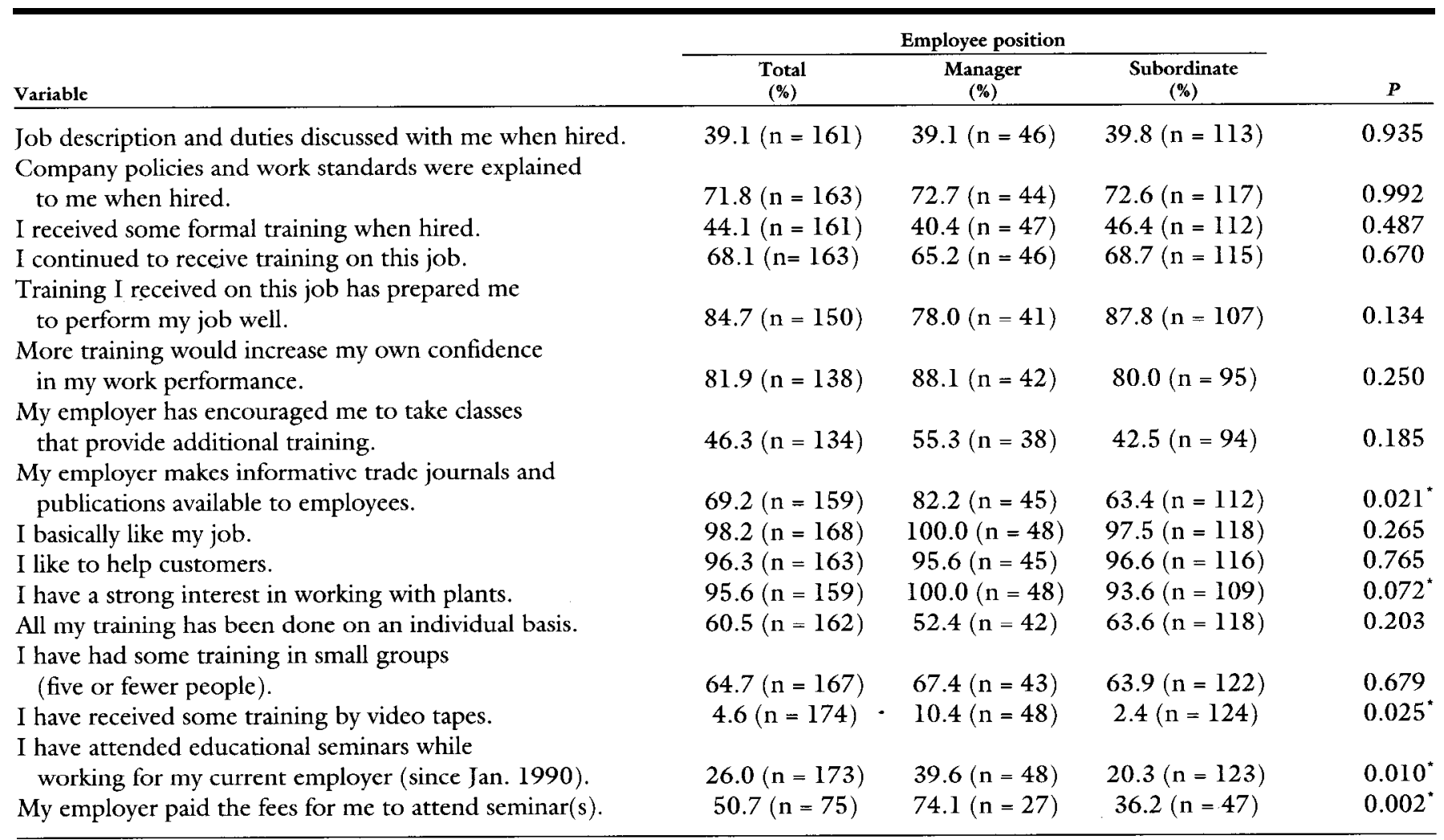

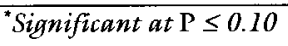


during the year for garden centers, the results for the mean hours worked may be higher than what might be found during slower months.

The mean number of months managers worked for their current employers during the year surveyed (June 1991 to June 1992) was nearly 3 months more than subordinate employees worked (Table 1). While more than half $(53 \%)$ of all respondents had worked 12 months during the year, the mean number of months worked for managers and subordinates was $<12$ months. Of those who had worked 12 months during the year, $83 \%$ had worked for more than 1 year for their current employers. Managers had worked 3 years longer for their current employers and 4.3 years longer in the horticulture industry than subordinates had. Managers also moved to other jobs less often, with a mean of 5.2 years worked for their current employers compared to a mean of 2.1 years for subordinate employees.

Slightly more garden center employees were male $(53 \%)$ than female (47\%). Fewer of the manager employees were male $(49 \%)$ than subordinate employees $(55 \%)$. The mean age of respondents was 33 , the median was
30 , and the mode was 22. Most managers were younger, creating a low mode. Yet, the presence of several older managers created a higher mean value.

The average garden center employee surveyed had completed 13 years of formal education. Fifty-four percent had received formal education beyond high school graduation. Twenty one percent had completed 14 years of formal education, and $19 \%$ were 4-year college graduates. While most respondents $(86 \%)$ had completed 12 or more years of formal education, only $10 \%$ of all respondents said they held a college degree in horticulture or a related area (Table 2). Managers had completed a mean of 14 years of formal education. The largest number of respondents $(90 \%)$ said they had no degree in horticulture. Almost three times as many managers (20\%) held college degrees than subordinate employees $(7 \%)$.

Less than $15 \%$ of respondents with horticultural training reported having education from each source listed (Table 2). Slightly more employees (13\%) listed high-school vocational programs, state-certified nurserymen courses, the Master Gardener program, and other college courses and seminars than either 2- or 4-year college programs. Among the $10 \%$ holding degrees, $22 \%$ held 2-year degrees, and $78 \%$ held 4-year degrees. Six percent of garden center employees was seeking further education in horticulture, with more employees working toward an associate degree than a bachelor degree. Because garden center employees have a varied educational background, garden center operators need to determine the level of horticultural knowledge employees have when they are hired. Since many employees indicated no horticultural background, they need a training program that uniformly provides all garden center employees the opportunity to obtain a fictional knowledge of horticultural work.

Less than half $(45 \%)$ of the employees who participated in this survey had received job promotions from their current employers. Yet most employees $(87 \%)$ had more job duties and responsibilities in their present position than when first hired. Seventyfive percent of those employees who had received promotions from their urrent employers had seen increases in their salaries, and the mean number

Table 4. Comparison of full-time and part-time employee groups on 16 job training variables.

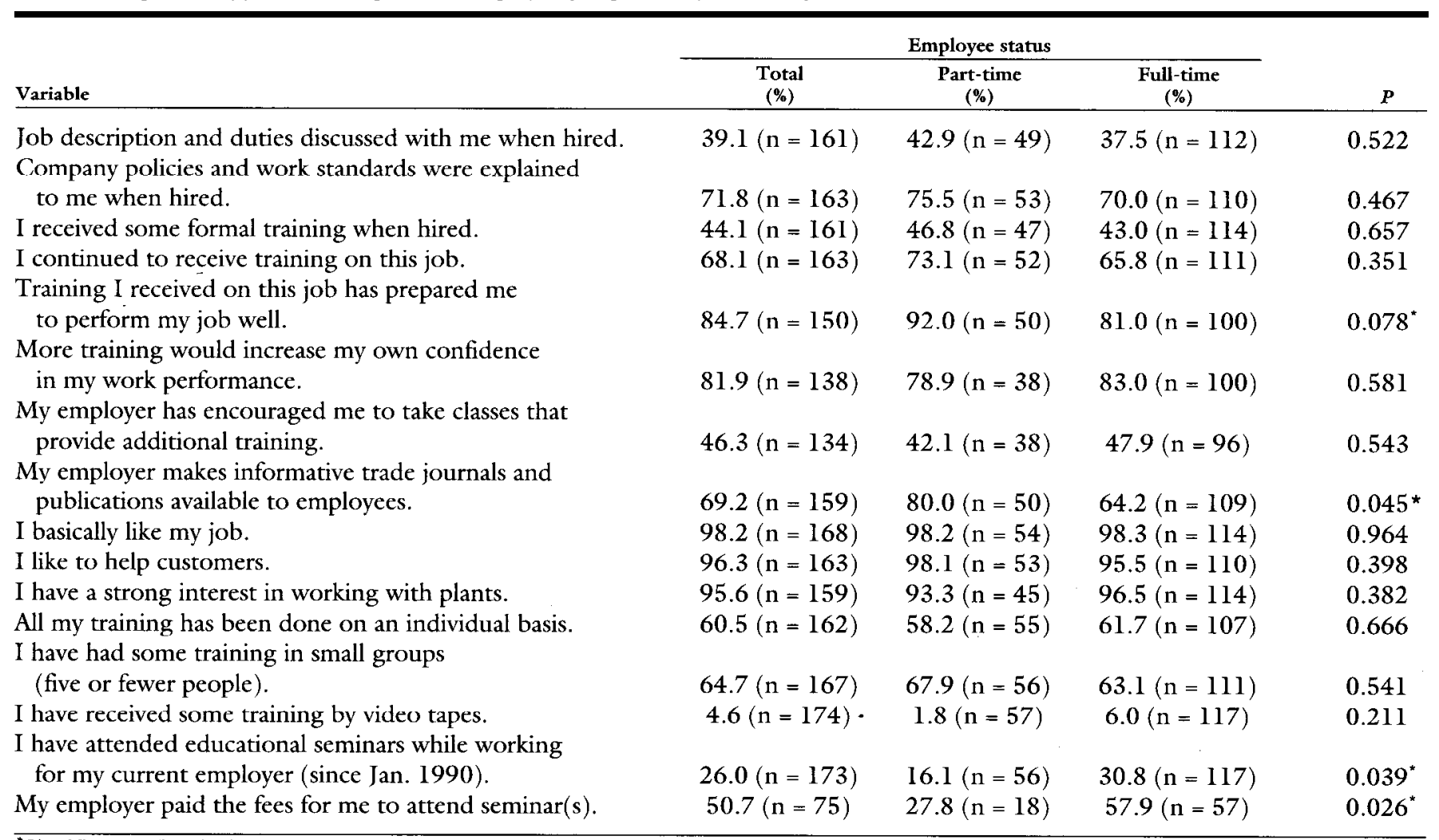

"Significant at $\mathrm{P} \leq 0.10$ 
of promotions employees had received from their current employers was two. Although the weekly mean salary was $\$ 200$ to $\$ 299$, almost half of the employees surveyed (48\%) said they earned less than that per week. The weekly mode salary (or most frequently mentioned salary range) for subordinate employees was $\$ 100$ to $\$ 199$ per week. Managers differed in salary range from subordinate employees with a weekly mean (and mode) salary range of $\$ 300$ to $\$ 399$ per week.

These data support two commonly observed phenomena in the garden-center industry: 1) a high percentage of employee job turnover and 2) employees hired on a seasonal basis and paid low salaries. Of the 12-month employees, the low percentage of job promotions employees receive, as well as the salary most employees are paid, indicates that garden center operators need to provide employees with incentives to stay and advance.

Fewer than half $(44 \%)$ of the garden-center employees surveyed received formal training when they were hired by their current employers (Table 3). Sixty-eight percent of respondents said that training continued on their job. Only about four out of ten employees (39\%) had a written job description of duties and responsibilities discussed with them when they were hired. Many more employees (72\%) received no written job description when hired, but had company policies and work standards explained to them. While most employees (85\%) felt the training they had received on their current jobs had prepared them to do their jobs well, $82 \%$ said if more training were available it would help them perform their jobs more confidently.

Manager and subordinate employees responded similarly to questions regarding whether their companies provided job training and whether they liked their work (Table 3). More managers than subordinates and part-time than full-time employees said that informative trade journals and publications were made available to them. Managers indicated a greater interest in working with plants than subordinate employees; however, both groups' responses were high, $100 \%$ and $94 \%$, respectively.

The garden center industry could improve its efforts to provide effective means of employee training. Responses from this survey indicated that $60 \%$ of employees received much of their training by a one-on-one method, an inefficient method of training employees. Sixty-five percent of employees said on the average they had received training in small groups of five or fewer employees from one to three times. Only $5 \%$ of the garden center respondents had received training by videotapes. The mean number of videotapes seen by those respondents was four. Managers were five times more likely to have received videotaped instruction than subordinate employees. Effectiveness and cost-efficiency may be different, so cost of training should be considered as well.

Only about one-fourth $(26 \%)$ of the garden center employees had attended any educational seminar or workshop that involved horticultural training since January 1990 while working for their current employers. The mean number of seminars attended was two, with $51 \%$ of those who attended seminars having the seminar fees paid by their employer. Twice as many of those who did attend seminars were managers (Tables 3 and 4). Managers and full-time employees attended educational seminars more often than subordinate and part-time employees as a method of training, and employers more often paid for their seminars.

When asked if employers regularly held meetings that allowed for discussion of employee questions, only $21 \%$ of the respondents said they met regularly, while $72 \%$ said they believed meetings with management would be beneficial to the employees.

We asked employees to indicate whether the amount of training they were given during four particular time periods (day 1, days 2-7, weeks 24, and months 2-6) was in the category of "none", "some", or "a lot" of training. Except for the first day on the job, the amount of training employees received decreased as time passed for the other three time periods during the 6 months surveyed. As time passed, responses of "no training received" increased from $10 \%$ of respondents on days $2-7$ to $20 \%$ on months $2-6$. The responses of "a lot of training" decreased from $48 \%$ of respondents on days $2-7$ to $25 \%$ on months $2-6$. Employee responses of "some training being received" during these three time periods consistently increased after the first day.

All groups of employees exhibited similar patterns. A greater percentage of subordinate employees said they received a lot of training on the first day and during the first week on the job than managers did. There were no differences between managers and subordinate employees for training received after the first week, which decreased for both groups over time.

Training for full-time and parttime employees differed on the first day and during the first week on the job. More part-time employees indicated they received a lot of training during these time periods. Since parttime employees are often seasonal workers, they are more likely to be

Table 5. Comparison of employee positions on seven frequently performed garden center job duty areas.

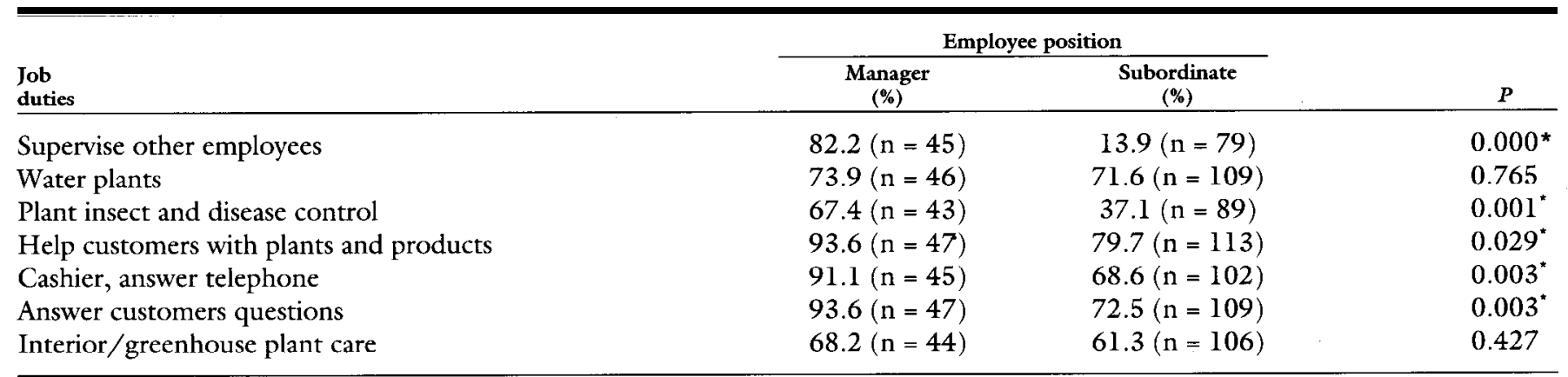

\footnotetext{
${ }^{7}$ Significant at $\mathrm{P} \leq 0.10$
} 


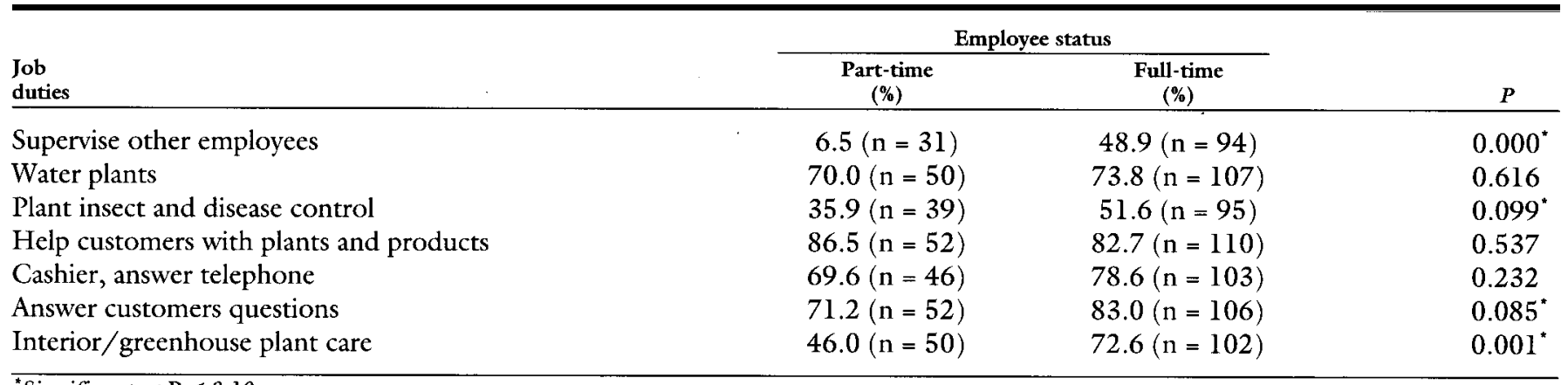

${ }^{*}$ Significant at $\mathrm{P} \leq 0.10$.

trained very soon after they are hired than fill-time employees are. The amount of training full-time and parttime employees received declined after the first week through the sixth month, with no differences between the groups.

Although the number of employees who said they received a lot of training as time passed decreased, employee responses to receiving some training as time passed consistency increased over the three time periods from $42 \%$ of respondents on days $2-7$ to $55 \%$ on months $2-6$.

Employees were asked to indicate how often they performed seven common garden center job duties (very often, sometimes, rarely, or never). In order to make comparisons between groups, responses were collapsed into two categories: 1) frequently for responses to "very often" and 2) infrequently for responses to "sometimes," "rarely," or "never."

The comparison of managers and subordinate employees on frequently performed duties indicates inefficient and costly training (Table 5). More managers performed five of the seven duties frequently (supervised other employees, performed insect and disease control of plants, helped customers with plants and products, answered customer questions, and performed cashier/telephone duties). About the same number of managers and subordinate employees indicated frequent performance of watering plants and interior/greenhouse plant-care duties. Subordinate employees should be trained to do more of these duties to allow managers more time for man- agement-level job duties.

More fill-time employees than part-time employees indicated their frequent performance of four job duties that require some training: supervising other employees, insect and disease control of plants, answering customer questions, and care of interior/ greenhouse plants (Table 6). About the same number of respondents in each group frequently performed three duties: watering plants, helping customers with plants and products, and performing cashier/telephone duties.

The results of this survey reveal much about the inefficiency and lack of training practices of many Alabama garden centers. Many provide employee training on an as-needed basis, resulting in the minimum use of employee skills. Most employees have little or no formal horticultural training, and many have little experience in horticulture. Yet most receive limited, if any, formal training when hired. Most of their training comes from one-onone instruction by the owner, manager, or supervisor, which is an inefficient means of teaching basic skills. Most employees feel that further training would be helpful. Training appears to be adequate overtime, according to employees, but they come into the job with little knowledge, especially with no written job description.

Master Gardeners, representative of devoted gardeners, emphasize quality and employee availability and knowledge when choosing where to buy their plants. Garden centers cannot compete on the basis of price, so they should capitalize on their strengths- good employees. Therefore, investing in training is essential to garden centers' competitiveness. Employees are the direct connection to the means of profit in garden centers - the customer. Garden centers already spend a large part of their operating costs on employees. This expense becomes even higher when a business experiences high employee turnover. Garden center owners should take advantage of the results of this study that indicate most garden center employees like their work and desire more training. They should also consider thorough job descriptions and more efficient means of instruction for employees, incentives to keep employees longer to make training investments more profitable, and professional development of employees to improve quality and service.

\section{Literature Cited}

Barton, S. 1988. Garden center management: a basic guide. Univ. of Delaware Coop. Ext., Newark, Del.

Ford, R.C. and C.P. Heaton. 1980. Principles of management: a decision-making approach. Reston Publishing Co., Reston, Va.

Higginbotham, J.S. 1992. Train for success. American Nurseryman 176(4):115-125.

Johnson, T.E. 1989. Analysis of retail nursery and garden centers in Alabama. MS thesis, Auburn Univ., Ala.

Niemiera, A.X., J. Innis-Smith, and C.E. Leda. 1993. Survey of garden center customer informational and marketing needs. J. Environ. Hort. 11(1):25-27.

Powell, R. 1991. Garden center customer survey report. Penn State Ext. 